\title{
Vocational Education and Training (VET) for Maritime Safety
}

\author{
Roberto W. Marpaung, ${ }^{1, a, *}$, Dinn Wahyudin ${ }^{1, b}$ \\ ${ }^{1}$ Postgraduate School Universitas Pendidikan Indonesia, Bandung Indonesia \\ a.robertomarpaung@student.upi.edub.dinn_wahyudin@upi.edu \\ *corresponding author
}

Keywords: $\quad$ Vocational Education and Training, Curriculum Relevance, Maritime Safety.

Abstract: Vocational education has been developed as a solution to unemployment problem in Indonesia. The government through The Ministry of Education and Culture has increased vocational education in number. However, in 2016, vocational education unexpectedly produced the largest number of unemployment compared to other kinds of education. The objective of this research was to describe qualitatively the relevance between Indonesian vocational education curriculum to the 21 st century skills and competencies in maritime. The writer applied library research method. The writer studied the curriculum of vocational schools and the 21 st skills and competencies concerning with maritime safety. The result showed that the curriculum of maritime vocational education is not relevant to 21 st century skills and competencies needed by maritime companies and industries. Irrelevance of vocational school curriculum to skills and competencies needed by industry and company has caused the explosion of unemployment in Indonesia. Consequently, the Indonesian government views vocational education as one of the focus of mid-term and long-term strategic plan for human resources management. For that reason, the government issued the Presidential Directive (INPRES) Number 92016 on Vocational School Revitalization. The president instructs ministers and governors to collaborate with vocational education institutions to create linked and matched institution to competencies and skills to industrial and company needs. The outcomes standards of vocational education must be suited to global standards or qualifications of maritime skills and competencies needed by the industries and companies. Vocational schools and institutions of maritime should consult and collaborate with The Ministry of Maritime and fisheries of Indonesia to produces human resources for maritime safety. Good collaboration between vocational schools, government and industries will result highly competitive and skillful seafarers and workers. Therefore, maritime companies and industries can collaborate with vocational schools in term of producing skillful and competent human resources..

\section{Introduction}

Human capital has become the focus of the national development of Indonesian government after infrastructure. A number of efforts done by the government to significantly develop human resources. Government believes that the quality of human resources figures outs the quality of education in one country. The development of human resources must be initiated through the development of 
education institutions. Unemployment has been a major problem in Indonesia for years. It significantly affects the growth of national economy. Indonesian statistics reported that the highest rate of unemployment were the vocational school outcomes [1]. Some problems have caused the explosion of labour surplus. The government believes vocational education irrelevance as one of the problem faced by manpower. Therefore, the government seriously re-evaluated the curriculum of vocational schools and education by involving the company and industry owners.

According to the national strategic plan, human resources become one of the mid and long terms national development focuses. This long term of national plan was made based on the sustainable development goals (SDGs) planned by The United Nations [2]. It can be said that human resources importantly affects the development of a country. The goal of education is to prepare people to be able to live together in the society. Education is a medium of preparing the graduates for good attitudes, habit and social knowledge. According to the national law of Republic of Indonesia number 20 issued in 2003, it is stated that the goal of education is to have the people educated for better lives [3]. Curriculum is one of the education components holding a very important role in the education system itself. In relation to the aim of education, Dewey believes that the goal of education is growth. In his view, there are two aspects of growth; experiences reconstruction and knowledge. Learners are demanded to be able to improve and grow their positive experiences. In this case, Dewey wants to express that, the aim of education is not only just for knowledge, but also life experiences as well as problem solving ability.

Curriculum is a set of components consisting of goals, content, process and evaluation used to achieve educational goal in particular country or region. Curriculum has a crucial role in education as it is the content and the written form of every plan of education. Misleading the curriculum will affect the quality of the education. The quality of education in Indonesia today is still low of competitiveness compared to other countries in the world especially in Asia [4]. The national curriculum changes as the presidents or the minister is replaced. Consequently, the government should provide retraining for the principals, curriculum leaders and the teachers. However, in fact, teachers are not well trained through the training event held by the government. Most teachers feel difficult to implement the new curriculum.

Vocational education is considered to be one effective solution for unemployment problem in Indonesia. The government then increase the number of vocational education and schools in Indonesia. The government expected that the outcomes of vocational school and education can compete nationally and internationally. However, in fact outcomes of vocational schools do not have work qualification as needed by company and industries. The curriculum of vocational schools in Indonesia is not relevant to the skills and competencies needed by the industry and companies.

The writer believes that the skills and competencies taught and trained in vocational schools does not suit the skills and competencies needed by the industry and companies. Whereas, the workforce in Indonesia has been categorized demand-driven. Then, the government should consider to revitalize vocational schools do the outcomes' skill is matched and linked to the industrial companies. The government should also consider about outcomes certification in order to fulfil the industrial demands of workers. The writer wants to provide data description to the government about vocational schools in Indonesia. He expected this paper can contribute to the development of human resources and industry. He also expected that this paper be used to consider education policy making especially on vocational school. 


\section{Literature Review}

\subsection{Vocational Education and Training}

Vocational Education and Training (VET) has developed for many years to increase the human resources quality. Vocational education is named differently in some countries. For example, in England, vocational education is known as TVET (Technical Vocational Education and Training), in Germany, it is known as VET (Vocational education and Training) and so on. Vocational education is established to produce skillful and competitive workforce or labor. in some countries, vocational education has contributed significantly to the economic growth. It is considered to be the best way of developing human resources to meet the need of industry and private sectors as well as the company.

Some Vocational education and training in Indonesia are separately defined. Vocational education can be referred to vocational schools, polytechnic, academy and higher secondary education. Vocational education in Indonesia was firstly built in 1536 by Portuguese named Antonio Galvano. Then, in 1853 the first vocational school was established. Holland rebuilt and established a school named Ambachts School Van Soerabadja in 1950. Then, after the independence of Indonesia from colonization, the government established more technical schools. After the explosion of population in Indonesia, the government seriously expanded and developed vocational schools. Now, vocational schools are increased in number.

Vocational education revitalization has been one of the chief focuses of the government today. It is predicted that Indonesia will experience extra demographical support in 2035-2045. Indonesia will experience the explosion of young and productive age of labor. This can both benefit the nation and workforce footage to national development. Therefore if the government can take the chance well, Indonesia will be one of superpower countries in the world. Indonesia will be one of well industrialized countries producing primary needs for people in the world. Vocational education is one of the national strategic plans of Indonesia today.

\subsection{Curriculum Development}

Curriculum is written form of what should be taught, how should the content delivered, and how it is evaluated. Curriculum development is a complex task involving various kinds of decisions. Curriculum developer needs to make decision about general aims and about more specific objectives of instruction [5]. Then, Oliva \& Gordon defines curriculum as a set of subjects faces a much simpler task than the school that takes upon itself responsibilities for experiences of the learner both inside and outside the learner [6]. Curriculum development is a more comprehensive process than syllabus design. Curriculum development includes the process that are used to select the needs of a group of learners, to develop aims or objectives for a program to address those needs, to determine an appropriate syllabus, course structure, teaching methods and materials and to conduct an evaluation of the subject program that results from these process [7]. Curriculum plays a very important role in education. Curriculum can be defined as a set of components forming a system used to gain the education goals in particular nation or region. According to Zais (1976), "the word curriculum comes from a Latin root meaning "racecourse," and traditionally, the school's curriculum has represented something like that figuratively speaking, of course-to most people. Curriculum can be viewed as an education plan deciding the design of education. Then, the design of education determines the process and the outcomes of the education itself.

There are four components of curriculum, they are; aims and objectives; content; teaching strategies/learning experiences, and content and teaching strategies organization [8]. According to Alexander Inglis [9], there are six functions of curriculum; the adaptive function; the integrating function; the differentiating function; the propaedeutic function; the selective function; and the 
diagnostic function. Curriculum consists of a number of plans in practice, in written form and of varying scope that delineate the desired learning experiences. Then, the curriculum may be a unit, a course, a sequence of courses, the school's entire program of studies - and may be encountered in the classroom or outside the classroom or school when directed by the personnel of the school. Curriculum is a product of its time ... curriculum responds to and is changed by social forced, philosophical positions, psychological principles, accumulating knowledge, and educational leadership at its moment in history. According to Zais there are four foundations of curriculum development, they are; philosophy and the nature of knowledge, society and culture, the individual, and learning theory [10]. The transaction position has its philosophical roots in experimental pragmatism, particularly in the work of John Dewey, whose work provides the philosophical underpinnings of inquiry approaches to curriculum. Therefore, curriculum development must suit to the current needs in order to solve any problems and fulfill every social need. In other words, vocational education curriculum development must also be suited to the current and future needs. So, the vocational education can fulfill and produce sustainable human resources.

Curriculum development is done by following some rules or principles. There are four sources of principle proposed by Oliva in curriculum development; empirical data, experiment data, folklore of curriculum and common sense. Moreover, in developing the curriculum, teacher or curriculum developer must also decide what model of curriculum development should be used. There are four models of curriculum development, they are; rational/objectives models, cyclical models, and dynamic/interaction models [11]. In addition, Taba explains four models of curriculum development, they are; The Tyler Model, Expanded Model, the Taba Model, and Oliva Model. It is stated that Tyler Curriculum Development Model can be expanded to be called expanded model. In short, in developing curriculum, a teacher or developer must be able to choose proper curriculum development model by principles must be followed.

Fullan defines implementation as the process of putting into practice an idea, program, or set of activities new to the people attempting or expected to change [14]. There are four models of curriculum implementation; Overcoming Resistance to Change Model, Organizational-Development Model, Concerns-Based Adoption Model, and Systems Model. The success of curriculum implementation is influenced by the curriculum leader. There five elements affecting curriculum implementation; support from the principal, support from teaching colleagues, support from students, and support from students' parents. Afterwards, Fullan, 1991 added several factor affecting the implementation based on the local characteristics; school district, community, principal, teacher and external factors. In relation to curriculum evaluation, Hamalik state that there are three things to consider in evaluating the curriculum, they are moral judgement, decision making, and value consensus.

\subsection{Curriculum Development of Vocational School in Indonesia}

Our world's education systems must now prepare as many students as possible for jobs at the top of the chart - the high-paying knowledge work jobs of today and tomorrow that require complex skills, expertise, and creativity. And many of the jobs of the future do not even exist today [12]. Vocational school in Indonesia is known as Sekolah Menengah Kejuruan (SMK). The goal of vocational education is to produce skillful and competent workers or outcomes. Therefore, vocational school is the right choice for the government to develop human resources in Indonesia. Unemployment problem will be solved if the government can organize linked and matched vocational schools to industrial and company needs.

One of the challenges faced by the government in revitalizing vocational schools in Indonesia is the facility with low standard [13]. Schools are increased in number without considering the 
environment, social needs and teaching and learning effectiveness. The number of vocational schools is not proportional to the students graduated from junior high school. Most vocational schools also do not employ productive teachers based on their expertise in each department. Therefore, before planning to establish a school, the government should have done need analysis.

Curriculum in vocational school is differently developed from general high schools. The comparison between theory $(60 \%)$ and practice $(40 \%)$ in general high schools has been developed for years. On the other hands, in vocational schools, the portion of practice $(60 \%)$ is higher than theory $(40 \%)$. There are several important things need to be considered when organizing the curriculum content, they are, significance, validity, relevance, utility, learnability, and students' interest. Therefore, in accordance with the workplace, the curriculum of vocational schools must be developed relevantly to the industrial and company needs.

Currciculum of vocational education in Indonesia is developed based on National Qualification Framework (KKNI), Indonesian National Standard of Work Competencies (SKKNI), and National Authority or Body for Work Certification (BNSP). The Ministry of Education and Culture, The Ministry of Industry Manpower and Transmigration cooperate to compile the work qualification standard and the competency certification for the outcomes of vocational school. However, in some countries, the standards are necessary but not sufficient to guarantee good TVET; a misconception we have found to be common in many parts of the world [15].

Indonesia is the largest maritime country in the world. Maritime has been one of supporting sectors to the economic growth of Indonesia. The government should provide regulation on maritime safety so the owner and the operators can get benefits together without jeopardizing their life. The maritime safety management systems are designed to make owners and operators responsible for the safe operation of their vessels protect the marine environment and ensure the safety of the vessel and its crew [16]. Maritime safety should be a focus of maritime development for sustainability.

\section{Method}

This article was written through a research by applying library research. The researcher collected the data through deep studies of sources consisting of research articles, related books, reports, regulation and policies as well as related news. The results of the research were presented descriptively. Qualitative researchers seek to understand a phenomenon by focusing on the total picture rather than breaking it down into variables. The goal of qualitative research is a holistic picture and depth of understanding rather than a numeric analysis of data [17]. In this case, the writer studies national laws related vocational education, journals on vocational education and so on. After presenting the results, the writer reduced the data to get the main points of the data collected. The reduced data were analyzed to get the core data. He then discussed the data before concluding the results of the research.

\section{Result and Discussion}

Curriculum in vocational schools is developed differently from curriculum in general senior high schools. Government, through The Ministry of Education and Culture has organized curriculum with particular time learning allocation namely $60 \%$ for practice and $40 \%$ for theory in the classroom. While in general senior high school the time allocation is $40 \%$ for practice and the rest for theory learning in the classroom. Vocational school's students should get more practice than theory learning so they can develop their skills based on their future work.

The government of Indonesia believes that in 2045 Indonesia will gain its golden age of productive age. One of the strategies planned by the government to reach the golden era of the nation is through revitalization of vocational education. Based on the studies, there are many countries successful in improving the national economy and industry through vocational education such as; USA, Germany, 
Japan China and other countries. Indonesian government wants to revitalize vocational education and training to prepare human resources as industrial and company needs towards workforce will rise. The question is, has the curriculum of vocational education been relevant to company and industry aspects?

The writer studied vocational education in three countries; USA, Germany and Japan. As a comparison to those countries, the writer also studied the vocational education in Australia. It was discussed how vocational education improve the economy and industry in the country. Each country has its own design and development style of curriculum. The conduct of education is different in some countries. Each country has unique philosophy affecting the education. They also develop curriculum based on the country philosophy. In this case, the writer studied education in three important countries; United States of America, Germany and Japan. Those countries are viewed as representing country for good educational system. Those three countries have their own educational characteristics and roles.

The 21 st century needs has changed culture and system of education in most countries in the world. Education practitioners are challenged to arrange good system and strategy so the students can face their lives when they are in school, in their families and in the society. Changes planned for 21st century engineers reflect cultural differences and societal needs in the three countries. One curriculum model will not serve all countries-even the European community cannot agree on one- but for a changing world good education is the best preparation for being able to adapt. An education that emphasizes general problem solving skills and lifelong learning ability will be important and as the economy shifts, people and societies who are appropriately educated will do best. The United States has taken more definite steps toward a concept of world-class education of engineers in the 21st century than Japan. Many initiatives are evident at several universities in the US: Penn State, University of California, Maryland, Arizona State, Cornell and Harvard, to mention a few. In Japan, only the University of Tokyo (mechanical engineering) and the Kanazawa Institute of Technology (engineering design) could be identified with pending changes. But, then again, Japan likes to wait for others to take the lead, select the most successful approach, improve on it, and adopt it for their own [18].

However, unlike America, Japan keeps tight control of its technological know-how to keep its Southeast Asian partners from revving up their economies. Developing countries can learn much from the developed nations by studying both the successes as well as the major mistakes made by even the most powerful countries. Note that during the Cold War, the "keiretsu" system and powerful government controls prevented the penetration of Japanese domestic markets by foreign firms. American manufacturers were permitted to participate in the Japanese market by primarily through technology sales. This strategy allowed technology flow into the Japanese economy while investment restrictions excluded foreigners and foreign control. Meanwhile, American business people, eager to reap short-term profits through sales of technology to Japan, inadvertently sold off their competitive advantage in high technology products without gaining significant market access in return.

Japan learnt important lessons from these US experiences and is determined not to repeat American mistakes. Japanese firms currently investing in Southeast Asia focus on market penetration and the control of outward flows of technology. Moreover, the Japanese government co-ordinate foreign aid with direct foreign investment to support Japanese penetration of local market. This ensures united and successful technology transfer, and helps business venture to profit. In the meantime, US firms may be in danger of soon finding themselves excluded from a Japan-centered regional economic block. In fact, in Thailand, Japanese manufacturers already control $90 \%$ of the automobile market. In Malaysia and Indonesia, Japan is the principal trading partner, manufacturer, and financial market leader. However, the country of the top of the developing nation ladder, South Korea, is an economic power-house of its own and does not allow - by law - any Japanese penetration 
of its markets. But South Korea can do little to stop the Japanese juggernaut in Southeast Asia. Understanding the social structures and cultural backgrounds, including the educational systems, in developed and developing countries is absolutely essential to maintain US competitiveness in the global marketplace of the 21 st century. We say this in view of the following: the US trade deficit with nearly all of our partners; our diminishing market shares in Southeast Asia (Indonesia, Malaysia, and Thailand) and the Far East (Japan, Korea, and China); our lack of coherent US government trade policy; and our failure to use foreign aid to promote American Financial Interests.

The ingredients identified in this paper for world-class education of global engineers in the 21 st century can ensure a better understanding of foreign practices, the development of innovative ideas for dealing with foreign competitors on a "level field" basis, adherence to the rights of having the largest and open consumer market in the world, and being prepared to learn from other countries. Given these attributes we can possibly overcome the current weakness of being the protector of all while our protégés are taking advantage of us wherever possible. It is indeed fortunate that at present the US is far ahead of Japan in curriculum initiatives for engineers in the 21st century; and, for once, we are taking a long-term view, albeit only in university education and not in government policy. So, now is the time to move ahead swiftly to implement the proposed university curricula changes in the United States. Perhaps, this will be our best investment for the future.

The three most important developed countries, the Web-Based curriculum produces improvements in students' acquisition of the 21st-century skills needed for success in today's high tech world [19]. Extensive, high quality vocational education and training are essential if enduring and widespread success in global markets is to be achieved [28, p. 24]. Australian educators and training professionals must develop and apply a training philosophy focused on developing a workforce with a sound basic education, together with more broadly based and flexible work skills. There must be an understanding that vocational training is a complementary aspect of a more general education. Above all, industry training must not be viewed as an activity to be deployed only when there is a particular task to mast. If this is the attitude to training, there will be evidence of only conditioned responses in the workplace. The restructuring of Australian industry demands much of educators, trainers, unions, management and workers [20].

The variation that has been noted in educational-vocational achievements of this cohort was not random but influenced by three broad groups of factors. The first of these groups of factors is largely beyond the control of the individual and included: gender, ethnicity, socio-economic status and geographical location. The second group of factors was educational and included early levels of achievement in literacy and numeracy (as well as later levels of school completion). The final set of factors included the motivational influences of high school interests in vocational areas. Furthermore there is an inevitable interaction between factors that has not been taken into account by this study.

On the basis of the information from this study, it appears that the most powerful influences on ultimate educational-vocational achievement might well be (in order of effect size): literacy, numeracy, the completion of year 12, type of vocational interest, gender, socio-economic status, ethnicity, and rurality. From a practical perspective there is scope to identify those persons with educational potential at a relatively early age, especially those who might otherwise be disadvantaged by their background. Second, it is also possible to outline educational and vocational options, given the pattern of interests and educational potential of a person in order to maximize their success and satisfaction. Third, it seems possible to plan on a large scale for ways in which to overcome some of those factors that circumscribe educational and training outcomes of Youth in Transition. For instance, groups of students who are potentially at risk might be identified and subtle educational, training and career interventions attempted in order to allow them to maximize their potential.

At the earliest stages of schooling an emphasis on enhancing the levels of literacy and numeracy might be considered and at the secondary school greater opportunities for the exploration of personal 
preferences might be provided. It has been noted that economic growth in and of itself has not been sufficient for tackling long-term unemployment (Committee on Economic Development of Australia, 2001; OECD, 2000) [21] but that educational and vocational achievement beyond the completion of secondary schooling results in higher labor force participation and lower levels of unemployment. The ultimate focus may need to be on ensuring a successful personal transition from education to employment by careful tailoring of individual interventions at some of the relevant educational, structural or personal factors identified in this article [22].

Learning must be IT-based and suitable to the current and future design. The techno-world needs IT skilled workers or work forces. The Envision IT curriculum produces improvements in students' acquisition of the 21 st-century skills needed for success in today's high tech world [19]. The planning of the curriculum must involve IT expert to analyze the needs, formulating the objectives, to chose curriculum implementation model and how the curriculum be evaluated. Since planning uses scarce resources, it should be engaged in as little as is necessary to maximize efficiency and economic growth. Minimalism will not necessarily mean less planning. Rather, planning will need to be better and, above all, more useful [23].

While developing curriculum in vocational education, every stakeholders should monitor the implementation and evaluate the curriculum. The data or the monitoring description can be gotten through Statistics bureau. Appraisal of new projects and occasional monitoring and evaluation of existing ones through cost/outcome analysis would require information on costs, skill levels before and after courses, and labor market outcomes. This information can be routinely collected by the training institutions themselves, but procedures would have to be established and instruments designed. Twenty-first century curriculum should be the curriculum can adapt to the current needs of skill and competencies or the future need of skills and competencies.

The Indonesian statistics report that the workforce in February 2017 was 131.55 million people. There are only 124.54 million people are employed. It means that the number of unemployment is 5.33 percent. Vocational school which was expected to solve unemployment solution contributes the largest number of graduates becoming unemployed. This fail was caused by the irrelevance of the vocational school curriculum to the skills and competencies needed by industry and company.

\subsection{1st Maritime Skills and Competencies}

21 st century learning and teaching has been one of the trending issues today. Academicians, education practitioners and researcher inevitably deliver their thoughts and arguments. The discussion has been about how to reach the goals of the teaching and learning. The students are demanded to have particular skills to be able to compete in digital era. They are trained and taught future occupation or profession they want. Occupational aspect has been one of the factors of 21 st century teaching and learning.

As one of the largest maritime countries in the world, Indonesia has put a focus on maritime vocational schools. It has been one of the main strategic plans of the government to develop and optimize maritime sector. The government organize and compile job title for maritime and the skills and competencies needed for each job title. The students are expected to have skills and competencies needed based on their future job or profession. The ministry of fishery and maritime has been instructed by the government to work together with the ministry of industry and the ministry of education and culture to provide mapping for maritime needs. The government believes if the three ministries work together, the maritime goal will be achieved.

Maritime schools and maritime training authority formulates the global maritime distress and safety system. The standards of teaching and training should be organized by the ministry of fishery and maritime by considering the standard compiled by IMO (International Maritime Organization). 
Besides constructing the training and the teaching standards for maritime schools or training institution, the government should also provide supervision authority to maintain the good quality of the teaching and training. Maritime schools have been believed to be the solution to support maritime industry development in Indonesia.

\subsection{Vocational Education Curriculum Relevance to 21st Century Maritime skills and Competencies}

One of the chief roles of education is to prepare future workers and citizens dealing with the challenge of their times. Education is the key to the economic survival in 21 st century. Education has been a medium or tool to make the students' dreams come true. Therefore, educating people is helping the realized their dreams. Education should be planed, conducted and evaluated comprehensively. The relevance between the schools' curriculum to the students' future has been important for the education.

National Qualification Framework of Indonesia (KKNI) is compiled by the government to address industrial or company needs. Besides KKNI, the government also compiles SKKNI National Work Competency Standard of Indonesia to specify job titles and skills and competencies needed in each job title. The outcomes of vocational schools get certification through Standards of Training \& Certification Body. The certificate is recognized in Indonesia and outside Indonesia. This certification will guarantee the students to get job in certain companies or industries.

\section{Conclusion and Recommendation}

Education is aimed at developing life skills and competencies so that people can live together. Therefore, education must be carried out based on society's need and necessity. Unemployment has been one of the national strategic plan focuses of Indonesian Government. Vocational education and training is the best solution to solve unemployment problem and to support upcoming huge industrial development especially maritime industry. Vocational education in Indonesia should have produced skillful workers. Vocational school curriculum must be linked and matched to the skills and competencies needed by company and industry. As one of the biggest maritime countries, Indonesia must strengthen the industrial development on maritime. Partnership with vocational schools must be affirmed by the company and industry to produce competent and skillful human resources on maritime. Government, education institutions, and company must stand together to decide the work qualification needed so when the students are graduated, the related company can directly accept them as the workers.

\section{References}

[1] Rencana Pembangunan Jangka Menengah (RPJM) 2015-2019, Rencana Pengembangan Pariwisata Nasional, Jakarta: Kementerian Perencanaan Pembangunan Nasional.

[2] BPS, Keadaan Ketenagakerjaan Indonesia Februari Hingga November 2017, Jakarta: Badan Pusat Statistik Indonesia, 2017.

[3] Undang-Undang Nomor 20 Tahun 2003 tentang Sistem Pendidikan Nasional, Jakarta: Kementerian Pendidikan dan Kebudayaan Republik Indonesia.

[4] N. S. Sukamadinata, Pengembangan Kurikulum: Teori dan Praktek, Bandung: PT. Remaja Rosdakarya, 2011.

[5] H. Taba, Curriculum Development: Theory and Practice, New York: Harcourt, Brace \& World Inc, 1962.

[6] P. F. Oliva and W. R. Gordon, Developing the Curriculum, New Jersey, USA: Pearson Education Inc, , 2013.

[7] J. C. Richards, Curriculum Development in Language Teaching, New York: Cambridge University Press, 2001.

[8] J. P. Miller and W. Seller, Curriculum Perspectives and Practices, London : Longman Inc. , 1985.

[9] O. Hamalik, Dasar-Dasar Pengembangan Kurikulum, Bandung: PT. Remaja Rosdakarya, 2013.

[10] R. S. Zais, Curriculum Principles and Foundations, New York: Harper \& Row, Publishers, Inc, 1976.

[11] M. Print, Curriculum Development and Design, Australia: Allen \& Unwin, 1993.

[12] B. Trilling and C. Fadel, 21st Century Skills: learning for life in our times, California: John Wiley \& Sons, Inc, 2009. 
[13] A. Hamid and P. Sudira, "Penanaman Nilai-Nilai Karakter Siswa SMK Salafiyah Prodi TKJ Kajen Margoyoso Pati Jawa Tengah," Jurnal Pendidikan Vokasi , pp. 139-152, 2013.

[14] M. G. Fullan, The New Meaning of Education Change, New York: Teacher College Published, 1991.

[15] N. Perry and D. Sherlock, Quality Improvement in Adult Vocational Education and Training, London \& Philadelphia: Kogan Page, 2008.

[16] New Zealand Maritime, HEALTH AND SAFETY; A Guide for Mariners, New Zealand : Maritime New Zealand, 2015.

[17] D. Ary, L. C. Jacobs and C. Sorensen, Introduction to Research in Education, California : Wadsworth, 2010.

[18] Z. T. Bieniawski and S. R. biniawski, "Curriculum Initiatives in the Unitd States, Germany, and Japan for WorldClass Education in the 21st Century," ASEE , pp. 189-196, 1996.

[19] M. V. Izzo, A. Yurick, H. N. Ngaraja and J. A. Novak, "Effects of 21st-Century Curriculum on Students' Information Technology and Transition Skills," Carreer Development for Exceptional Individuals , pp. 33(2) 95-105, 2010.

[20] A. A. Anderson, "Vocational Education and Industry Training in Australia," Education + Training , pp. 31-35, 1994.

[21] C. o. E. D. o. Australia, 2001.

[22] J. A. Athanasou, "Young People in Transition: factors influencing the educational-vocational pathways of Australian school-leavers," Education + Training Volume 43, pp. 132-138, 2001.

[23] M. Godfrey, "Planning for Vocational Educational Education, Training and Employment: A Minimalist Approach," International Journal of Manpower , pp. 206-227, 1997. 